Таким чином, зазначена побудова курсу - від теоретичної частини, крізь практику аналізу тестів, до перших спроб власного перекладу сприятиме ефективному опануванню матеріалу з виходом у власний творчий переклад. Зважаючи на прогрес сьогодення, а саме розвиток штучного інтелекту i його застосування у різних видах перекладу, розробка та введення курсу з поетичного перекладу до навчальної програми $є$ необхідною умовою для підтримання високого рівня навчання майбутніх перекладачів.

\title{
Література:
}

1. Абдрахманова О.Р. Роль переводческой ошибки в обучении переводу. Вестник Челябинского государственного университета. Серия: Филология. Искусствоведение. Вып. 88. № 6 (335). 2014. С. 6-9.

2. Коптілов В.В. Актуальні питання українського художнього перекладу. Київ : Дніпро, 1972. 132 с.

3. Ляшко Я. М. Поетичний переклад як особливий вид творчої діяльності (на матеріалі перекладів Р. М. Рільке). Наукові записки НДУ ім. М. Гоголя. Серія: Філологічні науки. Книга 4. 2014. С. 133-136.

DOI https://doi.org/10.30525/978-9934-26-073-5-2-66

\section{TO THE QUESTIONS OF FORMATION OF COLLECTIVE THINKING THROUGH THE CONNECTIVISM EDUCATIONAL PRINCIPLE IN DISTANT LEARNING IN MARITIME ENGLISH ON UNIFIED COMMUNICATION PLATFORM}

\author{
Ivasiuk N. A. \\ Candidate of Pedagogical Sciences, \\ Professor at the English Language Department \\ National University "Odessa Maritime Academy» \\ Odesa, Ukraine
}

Following our idea from the previous publications [1, 2, 3, 4] of creating Unified Communication Platform (UCP) for seafarers as international distant Maritime English (ME) learning instrument we made the attempt to create the sample learning environment for navigators, marine engineers and ship managers, which can be, of course, potentially expanded and improved in exponential ways. Previously we studied modern researches of scientists $[5,6,7,8]$ concerning distant learning technologies, analyses of differential 
approaches in teaching on-line and off-line for adult learners, given in them. And came to conclusion that the creation of the effective teaching process in the on-line mode or in blended mode of teaching - learning, in our case ME, requires insistive modelling as different as possible from classroom teaching. This modelling concerns specifically-oriented linguistic, including neurolinguistics, behavioural, including psychological aspects of teaching process. As some scientists assert [9, p. 20,32], it should lead to the synergistic model of distant learning education with the dominating idea of possibility of existent functioning training forms, thinking hierarchy of all participants of educational process and forms and ways of their interactive activity.

Distant learning mode enriches teaching process framework with vast variety of technical possibilities for presenting leaning materials and gains teacher's time, in our case of ME, in organizing learning modalities in the virtual linguistic laboratory. Video, audio application materials on the thematic topics, animation, interactive web-conferencing of teacher-learners, readymade presentations etc., should be so strongly content-based as to create «learning medium world» as a complex system or systems.

As coming from our practical experience, dynamic adaptness of ME teaching world would not be only of segmental, fractional nature but combined as «entity» like professional behavioural emergent. It is very important as UCP for seafarers is targeted at non-native speakers, levels A1/A2, reaching B1/B2. They may have difficulties in combining sequential linguistic events, presented to them while teaching-learning in professional behavioural discourse, then thematic event. The framework of ME teaching, distant learning environment should, in our opinion, following the ideas of scientific researches [10] be flexible, of linear and non-linear character, consisting of such agents or elements, which can be changed and adapted in response to learners' feedback, and upon interaction in the structured ways.

This, as we consider, will facilitate the process of upbringing the collective thinking of all participating learners in foreign sub-language of specialty and highlight the cognitive capacities of learners to be effectively motivated and realized in horizontal and vertical dimensions integrated.

Static meta-system as a part of complex system first should be used to place the learner inside the specific context horizontally where benchmarks are the popularized thematic words consistent with learners' intentions. Minimal set of core thematic words forming a string of interrupted theme-rheme will give the linguistic nativist possibility to overcome retardation in adaptability to linguistic progress from his initial language acquisition state to the expected input [11, 12]. Meta learning at the first stage of learning process itself (i.e. devoted to ME teaching-learning) will be facilitated by the teacher/tutor's efforts to decoding specific terminological information by decontextualizing it. And this process will involve simplification in perceiving ME sub-specialty 
structures. It is especially valuable for non-native speakers, students/learners who has difficulties of phonological, grammatical character. Trainers/tutors who are aimed at such group of students in on-line and off-line processing, create preliminary «target domain» of the thematic topic. Being embedded into this domain as topical here and topics adjacent to it the learner will acquire minimal basic pattern of experience, which then will be semantically prototypical for future language constructions with which they are associated.

We are still in the process of investigating the possibility how to create dynamic framework of communication platform as unified international distant learning instrument for seafarers. We consider it is rather complicated process and needs the convertible code of studied language with taking into account fluctuations from sub-code of native sublanguage of specialty to subcode of ME.

We believe that such knowledge behaviours as connecting, consuming, creating and contributing to the collective knowledge of distant learners will facilitate to explain humans linguistic behavioural performance and their development in specific context it concerns.

\section{References:}

1. Ivasiuk N., Shapo V. Unified English Language Communication Platform as a Service for seafarers. / The new Wave of Excellence in Maritime Education and training. The $1^{\text {st }}$ IMLA-IMEC-ICERS Conference, Philippines, 22-25 October, 2018

2. Ivasiuk N. A. To the Prospects of Adapting Seafarers of Different Nationalities as Non-native Speakers to the Unified Process of Learning Maritime English Language Communication Platform./ Science and Education a new Dimension. Philology. VII (60), Issue: 204, 2019 Sept. p. 34-37. Index Copernicus: ICV 2014; 70.95; ICV 2015; 80.87; ICV 2016; 73.35. Access mode: https://doi.org/10.31174/SEND-Ph2019-204VII60-07

3. Ivasiuk N. A. A $21^{\text {st }}$ Century Framework of Long-life Learning Maritime English by Future and Functioning Seafarers in the World./ International Scientific and Practical Conference «Challenges of Philological Sciences,Intercultural Communication and Translation Studies in Ukraine and EU Countries»,Ca'Foscari University of Venice,30-31October2020, Venice, Italy,2020,P.306-309.Access mode:https://doi.org/10.30525/0789934-588-90-7-83

4. Ivasiuk N. A. To the Prospects of Adapting Seafarers of Different Nationalities as Non-native Speakers to the Unified Process of Learning Maritime English Language Communication Platform./ Science without Boundaries Development in the 21st century, Budapest, 31 of August 2019. P. 34-38 
5. Larsen-Freeman D., Cameron L. Complex Systems and Applied Linguistics. Oxford, University Press, 2009. P. 229-233.

6. Keegan. D. Foundations of Distance Education. $\left(3^{\text {rd }}\right.$ ed). London: Routledge, 1996. P. 21.

7. Kerr. B. (2007d, February 3). MSG.7, Re: What Connectivism Is. Online Connectivism Conference: University of Manitoba. URL: http://ltc.umanitoba.ca/moodle/mod/forum/discuss.php?d=12

8. Arshad, K.; Imran, M. A. Increasing the Interaction Time in a Lecture by Integrating Flipped Classroom and just-in-time Teaching Concepts. June 2013. Compass Journal of Learning and Teaching 4 (7): 1-18. DOI: 10.21100/compass.v4i7.84. URL: https://journals.gre.ac.uk/index.php/ compass/article/view/84

9. Клепко С. Ф. Інтеграція і поліморфізм знання у вищій освіті. С. Ф. Клепко // Філософія освіти. 2005. № 2. С. 20-32.

10. Tomasello M. Constructing a Language: A Usage-based Theory of Language Acquisition. Cambridge, MA: Harvard University Press, 2003. P. 388.

11. Chomsky N. The Minimalist Program. (Current Studies in Linguistics 28.) Cambridge, MA: MIT Press, 1995. P. 213-226.

12. Diessel H. Linguistic Nativism. 2015. URL: http://www.personal.unijena.de/ x4diho/LA_Linguistic_nativism.pdf

DOI https://doi.org/10.30525/978-9934-26-073-5-2-67

\title{
PEER ASSESSMENT AS AN INSTRUCTIONAL METHOD IN ACADEMIC WRITING
}

\author{
Kalynovska I. M. \\ Candidate of Philological Sciences, Associate Professor, \\ Conversational English Department \\ Lesya Ukrainka Volyn National University \\ Koliada E. K. \\ Candidate of Philological Sciences, Full Professor, \\ Conversational English Department \\ Lesya Ukrainka Volyn National University \\ Lutsk, Ukraine
}

Academic writing testifies an intensive interest in peer assessment. This is due to changing conceptions of teaching and learning. In this context, peer 